\title{
Determination of Residual Chlorothalonil in Textiles
}

\author{
Chengyun Wang, Junfeng Lin, Tangtang Xie, Huiping Zou, Yalei Shen \\ The Testing and Technology Center for Industrial Products, Shenzhen Customs, Shenzhen, China \\ Email: wangchengyun2009@126.com
}

How to cite this paper: Wang, C.Y., Lin, J.F., Xie, T.T., Zou, H.P. and Shen, Y.L. (2020) Determination of Residual Chlorothalonil in Textiles. Journal of Materials Science and Chemical Engineering, 8, 106-114. https://doi.org/10.4236/msce.2020.84009

Received: November 29, 2019

Accepted: April 24, 2020

Published: April 27, 2020

\begin{abstract}
An effective method was established to determine the content of residual chlorothalonil in textiles by gas chromatography/mass spectrometry-selected ion monitoring coupled with ultrasonic extraction technique. Residual chlorothalonil in textiles was ultrasonically extracted using ethyl acetate as the extraction solvent. The extract was condensed and analyzed by gas chromatography/mass spectrometry in selected ion monitoring mode (GC/MS-SIM). The concentration of chlorothalonil was calibrated by the external standard method. Good linearity existed between the peak area and the mass concentration of chlorothalonil in the mass concentration range from $0.2 \mu \mathrm{g} / \mathrm{mL}$ to $42.8 \mu \mathrm{g} / \mathrm{mL}$. The equation was $\mathrm{A}=95,399 \rho-50,848$, with a correlation coefficient of 0.9999 . The limit of detection was $0.1 \mathrm{mg} / \mathrm{kg}$ for chlorothalonil. The blank samples were spiked at three concentration levels, and the spiked average recoveries changed from $81.9 \%$ to $95.4 \%$ while the relative standard deviation (RSD) changed from $1.8 \%$ to $5.2 \%$. The proposed method was simple, rapid, sensitive and the limit of detection could meet the limit requirements of relevant regulations. Commercially available textiles were measured by this method, and chlorothalonil at different concentration levels was detected in some samples.
\end{abstract}

\section{Keywords}

Chlorothalonil, Textile, Ultrasonic Extraction, GC/MS-SIM

\section{Introduction}

Chlorothalonil is a broad-spectrum and high-efficiency agricultural fungicide. Chlorothalonil interacts with glyceraldehyde triphosphate dehydrogenase in fungal cells and binds to cysteine-containing proteins in the enzyme, thereby destroying the activity of the enzyme. Therefore, the metabolism of fungal cells is 
destroyed and loses vitality [1]. Chlorothalonil has good bactericidal properties against fungi such as Ascomycetes, Basidiomycetes, and Deuteromycetes. Chlorothalonil is widely used in the United States, France, China, Brazil, and Japan. Chlorothalonil is widely used as a fruit preservative and insecticide in agriculture, and is used as an antifungal agent for leather, paint, paper and cloth in industry [2] [3]. However, chlorothalonil is a strong allergen that can cause delayed allergic dermatitis [4]. Chlorothalonil is listed in the list of Class 2B carcinogens by the World Health Organization's International Agency for Research on Cancer on October 27, 2019. The European Parliament issued Commission Implementing Regulation (EU) 2019/677 on April 29, 2019 to announce the non-renewal of the approval of the active substance chlorothalonil in accordance with Regulation (EC) No 1107/2009 [5]. The content of chlorothalonil in samples such as leather, food, environmental samples, paints and et al. can be determined by liquid chromatography, gas chromatography, gas chromatography-mass spectrometry, etc. [6]-[14], but no literature has been reported on the determination of residual chlorothalonil in textiles. In this paper, residual chlorothalonil in textiles was first ultrasonically extracted using ethyl acetate as the extraction solvents and the extract was then determined by GC/MS-SIM technique.

\section{Experimental}

Chlorothalonil standard (purity 99.0\%) was purchased from Dr. Ehrenstorfer $\mathrm{GmbH}$, Germany. Chromatographic pure methanol was purchased from Fisher Scientific, Pittsburgh, Pennsylvania, USA. Chlorothalonil was first dissolved in chromatographic pure methanol to prepare a standard stock solution with a mass concentration of $428 \mu \mathrm{g} / \mathrm{ml}$, then diluted with methanol to prepare a series of standard working solutions whose mass concentration was $42.8,21.4,10.7$, $5.4,2.1,1.1,0.5,0.2,0.1 \mu \mathrm{g} / \mathrm{ml}$, respectively.

Four positive samples were prepared through impregnation-baking technique. Chlorothalonil powder purchased from Sichuan Runer Technology Co., Ltd. was dissolved in water to obtain a high concentration aqueous solution of chlorothalonil. Polyerster lining cloth, nylon lining cloth, cotton lining cloth and wool lining cloth were selected to be blank substrates. They were first dipped into the aqueous solution of chlorothalonil for two days. They were then washed completely by water and dried. Therefore, four positive samples (sample 1\#: polyester, sample 2\#: nylon, 3\#: cotton, 4\#: wool) with different concentration levels of chlorothalonil were prepared.

The samples were cut into $5 \mathrm{~mm} \times 5 \mathrm{~mm}$ pieces by QYB-3 automatic sample preparation machine purchased from Zhongshan Qiyuan Machinery Technology Co. Ltd., China Accurately weigh $1.0 \mathrm{~g}$ of the sample and placed in a $35 \mathrm{~mL}$ glass reaction flask containing $30 \mathrm{~mL}$ of ethyl acetate. The sample was ultrasonically extracted at $45^{\circ} \mathrm{C}$ for $35 \mathrm{~min}$. The extract was then filtered to a chicken heart bottle and evaporated to near dryness in a Heidolph 4003 rotary evaporator purchased from Heidolph, Germany. The chicken heart bottle was trans- 
ferred to an N-Evap 112 nitrogen blowing apparatus purchased from Organomation Associates USA and slowly dried with dry nitrogen. The residue was dissolved in $1 \mathrm{~mL}$ of methanol, and the resulting solution was filtered used 0.45 $\mu \mathrm{m}$ filtering membrane purchased from CNW Technologist Co. Germany.

Analysis was carried out with an Agilent 6890A-7000B triple quadrupole gas chromatography/mass spectrometry supplied by Agilent USA. Chromatographic separation was performed on a DB-5MS column $(30 \mathrm{~m} \times 0.25 \mathrm{~mm} \times 0.25 \mu \mathrm{m})$ supplied by Agilent USA with an initial temperature of $90^{\circ} \mathrm{C}$. The temperature raised to $290^{\circ} \mathrm{C}$ at the rate of $40^{\circ} \mathrm{C} / \mathrm{min}$ after maintained for $1 \mathrm{~min}$ at the initial temperature and then maintained for $2 \mathrm{~min}$ at $290^{\circ} \mathrm{C}$. The carrier gas was high purity helium (purity $>99.999 \%$ ) and the carrier gas flow rate was $1 \mathrm{~mL} / \mathrm{min}$. The sample was injected in splitless mode and the injection volume was $1 \mu \mathrm{l}$. The inlet temperature, the transmission line temperature and the ion source temperature was $270^{\circ} \mathrm{C}, 280^{\circ} \mathrm{C}$ and $290^{\circ} \mathrm{C}$, respectively. The ionization mode was EI and the ionization energy was $70 \mathrm{eV}$. The qualitative analysis was carried out in full scan mode and the qualitative ion was $\mathrm{m} / \mathrm{z} 264, \mathrm{~m} / \mathrm{z} 268$, and $\mathrm{m} / \mathrm{z} 109$. The quantitative analysis was carried out in selected ion monitoring mode and the quantitative ion was $\mathrm{m} / \mathrm{z} 266$.

\section{Results and Discussion}

\subsection{Optimization of Analysis Conditions}

The intensity of the mass spectrometry signal in splitless injection mode was affected by the inlet temperature (factor A), ion source temperature (factor B), and carrier gas flow rate (factor $\mathrm{C}$ ). The effects of these three factors on the intensity of the mass spectrometry signal were first investigated separately. The results showed that the peak area of chlorothalonil reached the maximum when the inlet temperature was $260^{\circ} \mathrm{C}$ or the ion source temperature was $280^{\circ} \mathrm{C}$ or the carrier gas flow rate was $1.2 \mathrm{ml}$, respectively. Therefore, the orthogonal experiment was carried out according to the conditions in Table 1 . The peak area under the nine experimental conditions was determined, and the $\mathrm{k}$ value and the maximum difference of each factor were calculated, thus the optimal scheme was given out, as shown in Table 1. It could be seen from the data in Table 1 that the factor A had the largest maximum difference and the factor $\mathrm{B}$ had the smallest maximum difference. Therefore, the factor that had the greatest impact on the peak area was the inlet temperature (factor A), followed by the carrier gas flow rate (factor C) and the ion source temperature (factor $\mathrm{B}$ ). Through the orthogonal experiment, it was determined that the optimal scheme is $\mathrm{A}_{3} \mathrm{~B}_{3} \mathrm{C}_{2}$, that is to say, the $9^{\text {th }}$ condition in Table 1. The standard solution was analyzed under this conditions and the obtained GC/MS-SIM chromatogram was shown in Figure 1. A sharp peak corresponding to chlorothalonil appeared at about $5.659 \mathrm{~min}$ in Figure 1.

\subsection{Optimization of Ultrasonic Extraction Conditions}

The ultrasonic extraction efficiency depended on four factors such as the type of 
Table 1. The orthogonal experiment of analysis conditions.

\begin{tabular}{ccccc}
\hline No. & Factor $\mathrm{A} /{ }^{\circ} \mathrm{C}$ & Factor B $/{ }^{\circ} \mathrm{C}$ & Factor C/ml & Area \\
\hline $1 \#$ & 260 & 280 & 1.2 & $1,417,084$ \\
$2 \#$ & 260 & 270 & 1.0 & $1,539,826$ \\
$3 \#$ & 260 & 290 & 1.1 & $1,347,606$ \\
$4 \#$ & 250 & 280 & 1.0 & 921,204 \\
$5 \#$ & 250 & 270 & 1.1 & 878,664 \\
$6 \#$ & 250 & 290 & 1.2 & $1,069,374$ \\
$7 \#$ & 270 & 280 & 1.1 & $1,425,087$ \\
$8 \#$ & 270 & 270 & 1.2 & $1,584,478$ \\
$9 \#$ & 270 & 290 & 1.0 & $1,670,361$ \\
k1 & $1,434,839$ & $1,254,458$ & $1,356,979$ & \\
k2 & 956,414 & $1,334,323$ & $1,377,130$ & \\
k3 & $1,559,975$ & $1,362,447$ & $1,217,119$ & \\
Maximum difference & 603,561 & 107,989 & 160,011 & \\
Optimal scheme & & & & \\
\hline
\end{tabular}

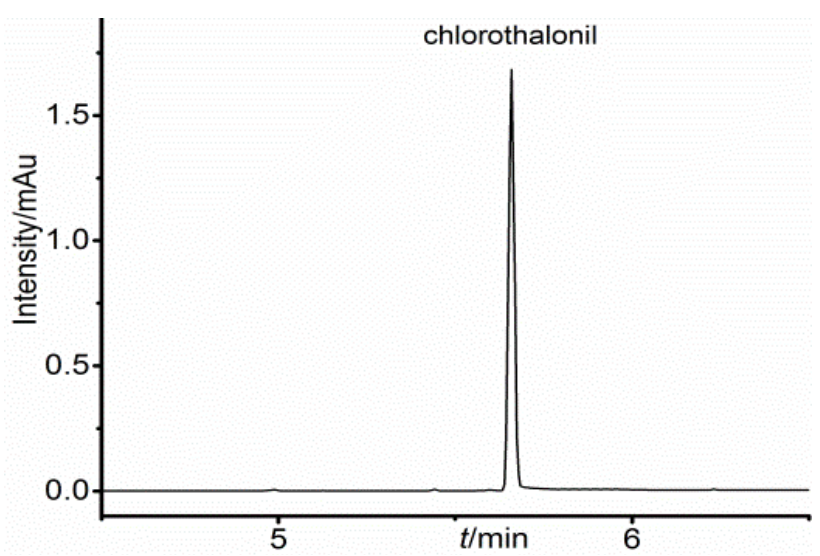

Figure 1. GC/MS-SIM chromatogram of chlorothalonil standard solution.

extraction solvent, extraction temperature (factor A), extraction time (factor B), and extraction solvent volume (factor $\mathrm{C}$ ). In order to investigate the effect of Factor A, Factor B and Factor C on the extraction amount, four self-made positive samples were ultrasonically extracted with acetone as the extraction solvent. In each experiment, only one factor changed while the other two factors remained the same. The results showed that the extraction amount reached the maximum when the extraction time was $30 \mathrm{~min}$ for sample $1 \#$ and sample $2 \#$ while the extraction amount reached the maximum when the extraction time was $35 \mathrm{~min}$ for sample $3 \#$ and sample $4 \#$. The extraction amount reached the maximum when the extraction temperature was $35^{\circ} \mathrm{C}$ for sample $2 \#$ and $40^{\circ} \mathrm{C}$ for sample 1\#, sample $3 \#$ and sample $4 \#$. The extraction amount reached the maximum when the volume of the extraction solvent was $20 \mathrm{ml}, 30 \mathrm{ml}, 20 \mathrm{ml}$ 
and $25 \mathrm{ml}$ for sample $1 \#$, sample $2 \#$, sample $3 \#$ and sample $4 \#$, respectively. In order to investigate the combined effects of these three factors on the extraction amount, an orthogonal experiment was designed according to Table 2. Four self-made positive samples were tested under each condition using acetone as the extraction solvent, and the extraction amounts were listed in Table 2 . The $\mathrm{k}$ value and the maximum difference of each factor were calculated according to data in Table 2 to give out the optimal scheme as shown in Table 3. The results showed that the optimal schemes of sample $1 \#$, sample $2 \#$, sample $3 \#$ and sample 4\# were $\mathrm{A}_{3} \mathrm{~B}_{3} \mathrm{C}_{3}, \mathrm{~A}_{3} \mathrm{~B}_{2} \mathrm{C}_{3}, \mathrm{~A}_{3} \mathrm{~B}_{3} \mathrm{C}_{3}$, and $\mathrm{A}_{3} \mathrm{~B}_{3} \mathrm{C}_{1}$, respectively. Taking all factors into consideration, the final optimal scheme was $\mathrm{A}_{3} \mathrm{~B}_{3} \mathrm{C}_{3}$, that is to say, the extraction temperature, extraction time and extraction solvent volume were $45^{\circ} \mathrm{C}, 35 \mathrm{~min}$, and $30 \mathrm{ml}$, respectively. Under the ultrasonic extraction conditions mentioned above, four self-made positive samples were ultrasonically extracted using common solvents such as ethyl acetate, acetone, $\mathrm{n}$-hexane, methanol, ethanol, acetonitrile, dichloromethane, petroleum ether, t-butyl methyl ether, ethyl acetate/dichloromethane $(1: 1, \mathrm{~V} / \mathrm{V})$ and $\mathrm{n}$-hexane/acetone $(1: 1, \mathrm{~V} / \mathrm{V})$ as the extraction solvents. The extraction results were shown in Table 4. Samples of different materials had different optimal extraction solvents. The optimal extraction solvent was ethyl acetate for sample $1 \#$ and sample $3 \#$ whose substrate was polyester and

Table 2. The orthogonal experiment of ultrasonic extraction.

\begin{tabular}{cccccccc}
\hline No. & $\begin{array}{c}\text { Factor } \\
\mathrm{A} /{ }^{\circ} \mathrm{C}\end{array}$ & $\begin{array}{c}\text { Factor } \\
\mathrm{B} / \mathrm{min}\end{array}$ & $\begin{array}{c}\text { Factor } \\
\mathrm{C} / \mathrm{ml}\end{array}$ & $\begin{array}{c}\text { Sample } 1 \# \\
/ \mathrm{mg} / \mathrm{kg}\end{array}$ & $\begin{array}{c}\text { Sample } 2 \# \\
/ \mathrm{mg} / \mathrm{kg}\end{array}$ & $\begin{array}{c}\text { Sample 3\# } \\
/ \mathrm{mg} / \mathrm{kg}\end{array}$ & $\begin{array}{c}\text { Sample } 4 \# \\
/ \mathrm{mg} / \mathrm{kg}\end{array}$ \\
\hline $1 \#$ & 40 & 30 & 25 & 1420 & 1462 & 1764 & 925 \\
$2 \#$ & 40 & 25 & 20 & 1572 & 1475 & 1994 & 928 \\
$3 \#$ & 40 & 35 & 30 & 2159 & 1576 & 1952 & 885 \\
$4 \#$ & 35 & 30 & 20 & 1178 & 1492 & 2007 & 984 \\
$5 \#$ & 35 & 25 & 30 & 2293 & 1811 & 2113 & 886 \\
$6 \#$ & 35 & 35 & 25 & 2058 & 1086 & 2377 & 1003 \\
$7 \#$ & 45 & 30 & 30 & 2012 & 1599 & 2299 & 968 \\
$8 \#$ & 45 & 25 & 25 & 1762 & 1524 & 2012 & 1046 \\
$9 \#$ & 45 & 35 & 20 & 2075 & 1651 & 2280 & 991 \\
\hline
\end{tabular}

Table 3. Analysis of data of the orthogonal experiment of ultrasonic extraction ( $\mathrm{mg} / \mathrm{kg})$.

\begin{tabular}{cccccccccccccccc}
\hline & \multicolumn{3}{c}{ Sample 1\# } & \multicolumn{3}{c}{ Sample 2\# } & \multicolumn{3}{c}{ Sample 3\# } & \multicolumn{3}{c}{ Sample 4\# } \\
\cline { 2 - 13 } & A & B & r C & A & B & C & A & B & C & A & B & C \\
\hline k1 & 1717 & 1537 & 1747 & 1504 & 1518 & 1357 & 1903 & 2023 & 2051 & 913 & 959 & 991 \\
k2 & 1843 & 1876 & 1608 & 1463 & 1603 & 1539 & 2166 & 2040 & 2094 & 958 & 953 & 968 \\
k3 & 1950 & 2097 & 2155 & 1591 & 1438 & 1662 & 2197 & 2203 & 2121 & 1002 & 960 & 913 \\
Maximum difference & 233 & 560 & 547 & 128 & 165 & 305 & 294 & 180 & 70 & 89 & 7 & 78 \\
Optimal scheme & & $\mathrm{A}_{3} \mathrm{~B}_{3} \mathrm{C}_{3}$ & & & $\mathrm{~A}_{3} \mathrm{~B}_{2} \mathrm{C}_{3}$ & & & $\mathrm{~A}_{3} \mathrm{~B}_{3} \mathrm{C}_{3}$ & & & $\mathrm{~A}_{3} \mathrm{~B}_{3} \mathrm{C}_{1}$ \\
\hline
\end{tabular}


Table 4. Extraction effects of various solvents $/ \mathrm{mg} / \mathrm{kg}$.

\begin{tabular}{cccccc}
\hline Solvent & Sample 1\# & Sample 2\# & Sample 3\# & Sample 4\# & Sum \\
\hline Ethyl acetate & 2430.9 & 1829.4 & 2826.3 & 1090.4 & 8177.0 \\
Acetone & 2094.8 & 1861.4 & 2278.6 & 1074.2 & 7309.1 \\
n-Hexane & 1755.7 & 1773.0 & 2168.7 & 1098.7 & 6796.2 \\
Mathanol & 1619.0 & 2191.5 & 2373.3 & 1088.7 & 7272.4 \\
Ethanol & 2011.8 & 1959.2 & 2763.0 & 1104.7 & 7838.6 \\
Acetonitrile & 2322.2 & 1921.1 & 2670.3 & 1099.9 & 8013.4 \\
Dichloromethane & 2294.3 & 2268.8 & 2434.5 & 981.0 & 7978.6 \\
Petroleum ether & 2034.5 & 1855.0 & 1922.5 & 978.4 & 6790.4 \\
t-Butyl methyl ether & 1221.4 & 1703.8 & 1944.9 & 780.4 & 5650.4 \\
Ethyl acetate/dichloromethane(1:1,V/V) & 2088.4 & 1982.3 & 2451.9 & 1070.3 & 7592.8 \\
n-Hexane/acetone(1:1,V/V) & 1693.7 & 1771.0 & 1949.8 & 823.3 & 6237.8 \\
\hline
\end{tabular}

cotton, respectively. The optimal extraction solvent was dichloromethane and ethanol for sample $2 \#$ and sample $4 \#$, respectively whose substrate was nylon and wool, respectively. In order to ensure that the final optimal extraction solvent had a good extraction effect on all samples, the solvent with the largest total extraction amount was selected as the final optimal extraction solvent. According to the data in Table 4, the total extraction amount reached the largest when ethyl acetate was used as the extraction solvent. Therefore, the ultrasonic extraction conditions were finally optimized as follows: $30 \mathrm{ml}$ of ethyl acetate was used as the extraction solvent, the extraction temperature was $45^{\circ} \mathrm{C}$, and the extraction time was $35 \mathrm{~min}$.

\subsection{Linearity and Limit of Detection}

The sensitivity was tested by analyzing a series of standard working solution. Linear calibration curve was studied by plotting the pear areas against the mass concentrations of chlorothalonil. Excellent linearity was found over the range of $0.2 \mu \mathrm{g} / \mathrm{ml}$ to $42.8 \mu \mathrm{g} / \mathrm{ml}$ for chlorothalonil and the correlation coefficient was 0.9999 . The limit of detection (LOD) was taken when the ratio of signal to noise $(S / \mathrm{N})$ was three and the limit of detection (LOD) was $0.1 \mathrm{mg} / \mathrm{kg}$ for chlorothalonil.

\subsection{Recoveries and Precision Studies}

Three levels $(1.1 \mu \mathrm{g}, 5.4 \mu \mathrm{g}$ and $21.4 \mu \mathrm{g})$ of chlorothalonil were added to polyester lining cloth, nylon lining cloth, cotton lining cloth and wool lining cloth, which originally contained no chlorothalonil. The spiked average recoveries and the relative standard deviations (RSDs) of nine replicate measurements were determined as shown in Table 5. The spiked average recoveries ranged from $81.9 \%$ to $95.4 \%$ while the relative standard deviations (RSDs) varied from $1.8 \%$ to $5.2 \%$.

The inner-day and inter-day RSDs were used to examine the repeatability of the proposed method. Inner-day precision was evaluated using nine injection 
containing chlorothalonil at $5.4 \mu \mathrm{g} / \mathrm{ml}$ in 1 day while inter-day precision was assessed using nine determinations containing chlorothalonil at $5.4 \mu \mathrm{g} / \mathrm{ml}$ on different days. The inner-day and inter-day precision $(n=9)$ for chlorothalonil was $2.5 \%$ and $3.9 \%$, respectively, which could be considered acceptable. This result demonstrated that no significant influence of the chlorothalonil stability on the experimental results was found during sample preparation and GC/MS-SIM determination.

\subsection{Analysis of Commercial Textile Samples}

To evaluate the applicability of the proposed method, the contents of residual chlorothalonil in 157 commercial textile samples were determined using the previous described procedure. Quantification was based on the external standard method using calibration curves fitted by linear regression analysis. Chlorothalonil was detected in a striped knitted cotton women's trousers sample and the content of chlorothalonil was $456.3 \mathrm{mg} / \mathrm{kg}$. GC/MS-SIM chromatogram of this positive sample was shown in Figure 2. A sharp peak corresponding to chlorothalonil appeared at about $5.655 \mathrm{~min}$ in Figure 2.

\section{Conclusion}

An effective method was established to determine the content of residual chlorothalonil in textiles using gas chromatography/mass spectrometry in selected ion monitoring mode, coupled with ultrasonic extraction technique. A good

Table 5. The recovery experiments.

\begin{tabular}{cccccccccc}
\hline Sample & $\begin{array}{c}\text { Added } \\
/ \mu \mathrm{g} / \mathrm{mL}\end{array}$ & $\begin{array}{c}\text { Average } \\
\text { recovery/\% }\end{array}$ & $\begin{array}{c}\text { RSD } \\
/ \%\end{array} / \mu \mathrm{g} / \mathrm{mL}$ & $\begin{array}{c}\text { Average } \\
\text { recovery/\% }\end{array}$ & $\begin{array}{c}\text { RSD } \\
/ \%\end{array} / \mu \mathrm{gdded} / \mathrm{mL}$ & $\begin{array}{c}\text { Average } \\
\text { recovery/\% }\end{array}$ & $\begin{array}{c}\text { RSD } \\
/ \%\end{array}$ \\
\hline Cotton & 1.1 & 83.2 & 4.5 & 5.4 & 89.6 & 3.2 & 21.4 & 95.4 & 1.8 \\
Polyester & 1.1 & 81.9 & 4.9 & 5.4 & 87.9 & 4.1 & 21.4 & 94.7 & 2.8 \\
Wool & 1.1 & 82.3 & 5.2 & 5.4 & 88.5 & 3.6 & 21.4 & 91.5 & 2.4 \\
Nylon & 1.1 & 82.6 & 4.7 & 5.4 & 91.3 & 2.9 & 21.4 & 93.6 & 2.2 \\
\hline
\end{tabular}

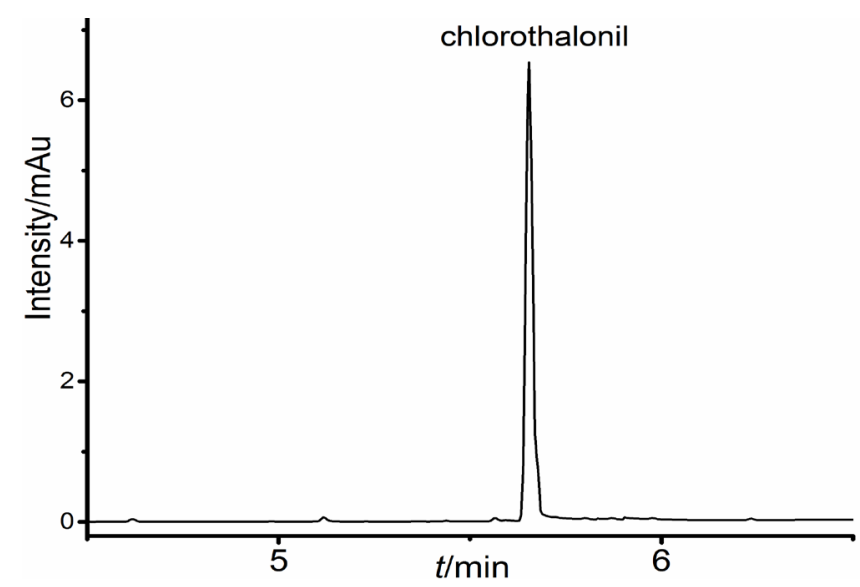

Figure 2. GC/MS-SIM chromatogram of a positive sample. 
linearity existed between the peak area and the mass concentration of chlorothalonil in the mass concentration from $0.2 \mu \mathrm{g} / \mathrm{ml}$ to $42.8 \mu \mathrm{g} / \mathrm{ml}$. The proposed method was simple, rapid and sensitive. The limit of detection was as low as 0.1 $\mathrm{mg} / \mathrm{kg}$, far lower than the requirements of relevant regulations. The proposed method was applied in the routine analysis of chlorothalonil in commercially available textiles and chlorothalonil was detected in some of the samples.

\section{Acknowledgements}

This work was supported by National Key R \& D Program of China "Development and application of multi-parameter \& nondestructive testing instrument for cross-border goods" (No. 2017YFF0108900).

\section{Conflicts of Interest}

The authors declare no conflicts of interest regarding the publication of this paper.

\section{References}

[1] Yang, G.L. (2014) Chlorothalonil Market Analysis. Pesticide News, 6, 31-31. http://www.agroinfo.com.cn/news_detail_3482.html

[2] Hua, N.Z. (2019) Review of Four Outstanding Models in Protective Fungicides. Pesticide Market Information, 4, 23-27.

[3] Ma, J.F., Chen, L.L., Zhou. M. and Yan, L.Q. (2016) A Flame Retardant Antibacterial Coating for Textile Fabric. CN Patent No. 105421064A.

[4] Wu, B.J. and Li, T.C. (2010) Analysis of Allergic Dermatitis Caused by Chlorothalonil. Practical Preventive Medicine, 17, 2238-2239.

[5] (2019) Commission Implementing Regulation (EU) 2019/677 of 29 April 2019 Concerning the Non-Renewal of the Approval of the Active Substance Chlorothalonil in Accordance with Regulation (EC) No. 1107/2009 of the European Parliament and of the Council Concerning the Placing of Plant Protection Products on the Market, and Amending Commission Implementing Regulation (EU) No. 540/2011. Official Journal of the European Union, L114, 15-17.

[6] Jin, J., Yu, L.Y., Dong, W., Wu, M.R. and Liu, S.R. (2014) Study on Determination of Carbendazim, Chlorothalonil and Thiophanate-Methyl in Leather. Leather and Chemicals, 31, 16-20.

[7] Ouming, L.Q., Wu, F.Z., Tong, Z.D., Shen, Y.Y. and Wang, H. (2007) Determination of Chlorothalonil Residues in Vegetable by High Performance Liquid Chromatography. Chinese Journal of Health Laboratory Technology, 17, 641-642.

[8] Chen, X., Liu, J., Liu, Q., Cheng, Y, B. and Shen, J. (2017) High-Efficiency Determination of Chlorothalonil Residues in Fruit and Vegetable Juice by Gas Chromatography. Rural Economy and Science-Technology, 28, 57-58.

[9] Tang, Y.J., Wang, G.H. and Niu, G.C. (2010) Determination of the Residues of Chlorothalonil and Pyrethroids Invegetables by Capillary Column Gas Chromatography. China Brewing, 221, 162-163.

[10] Wang, T.L., Liu, T.C., Li, B., Tan, W., Yang, M. and Wang, H.B. (2014) Determination of Chlorothalonil Pesticide Residues by SPE-GC. Chinese Journal of Environmental Engineering, 8, 2129-2132. 
[11] Ye, Y.L. (2017) Determination of Chlorothalonil by Gas Chromatography-Mass Spectrometry. Journal of Green Science and Technology, 24, 63-64.

[12] Montesinos, I., Sfakianaki, A., Gallego, M. and Stalikas, C.D. (2015) Graphene-Coated Cotton Fibers as a Sorbent for the Extraction of Multiclass Pesticide Residues from Water and Their Determination by Gas Chromatography with Mass Spectrometry. Journal of Separation Science, 38, 836-843. https://doi.org/10.1002/jssc.201400957

[13] Cao, X.Q., Li, F., Chen, G.T., Mao, Q.L., Yang, F. and Yang, Z. (2019) Determination of 10 Preservatives in Fruits by Ultra High Performance Liquid Chromatography Tendem Mass Spectrometry. Food Science. http://kns.cnki.net/kcms/detail/11.2206.ts.20190710.0853.006.html

[14] Jiang, Y., Liu, W.D., Zhang, Y. and Shao, Q.F. (2019) HPLC Determination of 4 Biocides in Waterborne Coating. PTCA (Part B: Chem Anal), 55, 923-926. 